\title{
RESEÑA: DEL AMOR Y DE LA MUERTE EN LOS RELATOS DE CAROLINA INVERNIZIO. YOLANDA ROMANO MARTÍN (INTRODUCCIÓN Y TRADUCCIÓN) ${ }^{1}$
}

\author{
Nadia La Mantia ${ }^{2}$
}

\begin{abstract}
Yolanda Romano Martín (introducción y traducción). Del amor y de la muerte en los relatos de Carolina Invernizio. Sevilla: Arcibel Ediciones, 2018. ISBN: 9788415335757.
\end{abstract}

Invisible y sin embargo presente. Olvidada e inmortal ahora más que nunca. Refinada burguesa y amante de lo escabroso. Alabada por sus admiradores, menospreciada y renegada por los conservadores y los puristas de la lengua y de la literatura italiana. Todo esto fue, y es, Carolina Invernizio.

Hoy, cien años después de su muerte, es cuando hay que rescatarla del olvido, reinterpretar su obra desde una perspectiva moderna, devolverle el sitio que merece, descubrir y conocer el enorme legado del que puede finalmente alardear la historia de la literatura italiana.

$\mathrm{Su}$ prepotente y polémica presencia en el panorama literario italiano en la complicada fase del post-unitarismo, marcó el comienzo de la literatura de consumo y también de la industrialización del fenómeno cultural: entre finales del siglo XIX y principios del XX, entre las clases medio altas de la burguesía del Belpaese, se desarrolló un tipo de literatura que aprovechaba tanto las temáticas tardo-románticas

\footnotetext{
${ }^{1}$ Fecha de recepción: 10/11/2019.

Fecha de aceptación: 10/11/2019.

${ }^{2}$ Profesora Adjunta/Lectora de Lengua Española en el Dipartimento di Scienze Umanistiche e Sociali (DUMAS) de la Universitá di Sassari, Italia; $₫$ lamantia1979@gmail.com.
} 
retomadas por los decadentistas europeos, como los tópicos de matriz dannunziana -la exaltación nacionalista, el erotismo, lo macabro- llevados a su máxima expresión y al mismo tiempo despojados de ese estetismo refinado y elitista, en favor de una narrativa más asequible, cercana y, a veces, controvertida.

En el momento en que Italia acababa de vivir su lucha por la independencia e intentaba forjar su propia identidad cultural y social, los escritores extranjeros seguían dominando el mercado editorial con sus novelas populares y las obras clásicas, mientras los autores italianos de mayor éxito podían aspirar a vender como máximo unos veinte mil ejemplares. En este intricado escenario, fuertemente caracterizado por el imperante dominio patriarcal en todos los ámbitos de la vida y la sombra de la misoginia que acechaba implacable en el microcosmo literario, el público de lectores de Carolina Invernizio hizo que se convirtiera en el fenómeno editorial italiano más importante del momento.

Fue considerada la precursora de aquella producción que más tarde se calificaría como literatura barata, subliteratura o paraliteratura, y encarnó el estereotipo de escritor de aquella narrativa popular menospreciada por la crítica y sin embargo amada por una audiencia preeminentemente femenina: al hilo de los feuilletons franceses de Balzac, Sue, Hugo y Dumas, esta reina incuestionable del romanzo d'appendice, fue asimismo la iniciadora de un género peculiar y novedoso- la novela popular rosa con claros tintes góticos- que consiguió atrapar en sus tramas a todos aquellos lectores que seguirían leyéndolas con avidez en las sucesivas cuatro décadas.

Pese a que, en su novela más famosa, Il bacio di una morta (1889), ella se dirigiera sin tapujos a sus fieles lectoras, Carolina Invernizio quiso que todo su público -burgués y obrero- se adentrara por los entresijos de sus historias románticas 
impregnadas de crueldad, morbo y sangre: su afición por las temáticas escabrosas e inadecuadas es su marca personal, algo que demostró tener desde sus primeros pinitos literarios siendo aún adolescente y estudiante del Instituto Magistral de Florencia, algo que casi le costó la expulsión.

Tras estos tímidos comienzos, la autora se lanzó al mundo editorial trabajando más por gloria que por dinero, creando historias y mundos hasta el fin de sus días: su obra hoy cuenta con más de 120 novelas que demuestran el inmenso y desbordante poder creativo de la que se describía a sí misma como una donna perbene.

Carolina Invernizio supo conjugar de manera sorprendente sus facetas de mujer burguesa, buena madre y fiel esposa con la de autora de novelas cruentas, horribles y sensacionales: fue una escritora minuciosa y constante, metódica y puntual, que buscaba el título de su obra antes que nada, porque el escenario -Turín y Florencia-, los personajes -el famoso bandido Antonio Bruno, la Condesa Lara o Annetta Durini- y la trama, ya llevaban tiempo existiendo en las crónicas de los periódicos y en su mente.

Leer cualquiera de sus obras hoy en día podría suscitar reacciones diferentes y discordantes: podrían satisfacer al amante del mal gusto, escandalizar a la feminista, entretener al experto de narratología, sacudir al sociólogo o simplemente divertir al lector curioso. Su microcosmos está plagado de amores, adulterios, violencia, asesinatos sangre, venganza y engaños, y sus protagonistas son heroínas y villanos, víctimas y traidores que se materializan paulatinamente ante nuestros ojos gracias al poder de una narración en la que domina un estilo directo, turbador y sensacionalista, al igual que los títulos: El delito de una madre, La confesión de una suicida, La venganza de un marido o Pequeñas mártires. 
Los lectores somos testigos de pecados inconfesables, traiciones perversas, mujeriegos sin escrúpulos, jóvenes extraviadas, maridos desalmados y mujeres mártires: en cada historia queda patente la obsesión de la autora por el tema de la muerte en todos sus matices y la sempiterna y paradigmática lucha entre el bien y el mal.

Considerando los tiempos en los que publicó sus novelas y las pautas establecidas por los cánones literarios de la época, con gran osadía Carolina Invernizio otorgó a todas las mujeres de sus historias el papel de protagonistas absolutas, maltratando, ridiculizando y, en ocasiones, humillando a los hombres, relegados a meros figurantes. El repertorio de personajes femeninos creados por la autora abarca diferentes tipologías que juegan con los contrastes y las oposiciones -la mujer fatal, la virgen inocente, la implacable seductora, la investigadora novata, la fea, la sorda, la jorobada, la loca, la paralítica- y todas ellas aparecen claramente estigmatizadas por su nombre, Sirena, Satanella o Fosca encarnan el Mal, mientras que Aurora, Chiara o Angela son la personificación del Bien.

Puede parecer contradictoria y paradójica, hoy igual que entonces, la armoniosa convivencia de las dos facetas de Carolina Invernizio, mujer pía y religiosa, madre atenta y esposa entregada, y a la vez autora de historias y relatos cruentos, morbosos y sangrientos. Sus libros, en palabras de Gramsci, son ilógicos, intricados y lúgubres, mientras que su fiel público de lectores es insaciable, incrédulo y simplón: aun así, ningún otro escritor logró alcanzar la popularidad de la que ella pudo presumir en sus tiempos.

Adentrémonos, pues, como uno de esos ávidos y curiosos lectores de antaño y descubramos el sufrimiento de Pietro, un enterrador desgraciado que se preguntaba si "tan infame" era su oficio para que una mujer aborreciera hasta el roce de esa mano que 
tantos cuerpos había sepultado; el dolor de Teresa, violada por hombres "desenfrenados, ebrios, lujuriosos, sedientos de orgía, incapaces de sentir piedad" ; la perfidia de la princesa Marta, quien “con la mano levantada como si maldijera, los ojos abiertos de par en par, amenazadores, la boca retorcida y una sonrisa horrible", se vengó de su único hijo en su día más feliz; el suplicio de Olga, desgarrada hasta la muerte por los ganchos de hierro del temible knout ante la mirada impasible de su marido; y el feroz arrebato homicida de la pequeña Pinota, quien así protegió para siempre a su hermanita Clarina de la violencia de su madrastra, esa "vieja arpía con voz ronca y siniestra".

Y conozcamos a la vez el lado tierno de una esposa traicionada que quiso perdonar a su marido y volver a empezar; el patriotismo de un soldado que antes de morir acribillado por una ametralladora enemiga y aplastado por el cadáver de su fiel compañero, juró fidelidad a la patria; y el orgullo de una madre soltera, seducida y abandonada, quien prefirió suicidarse antes que vender su cuerpo.

Carolina Invernizio fue amada y odiada: supo conquistar el corazón y la imaginación de toda Italia y medio mundo, ignoró las feroces críticas de los misóginos del tiempo y siguió creando mundos e historias hasta el último de sus días.

Hoy, los lectores del siglo XXI, podemos perdernos en esas páginas, imaginar ser esas mujeres traicionadas o esos asesinos vengadores, compadecerlos o condenarlos, respetarlos o despreciarlos: tal vez este fuera el deseo más grande de esta sorprendente autora. 